\title{
Vibration Analyses of a Single Osteoblast in Vitro Using the Finite Element Method
}

\author{
Li-ping WANG ${ }^{1, \text { a }}$, Hung-yao HSU ${ }^{2, c}$ and Cory J. XIAN ${ }^{1, ~ b, ~ * ~}$ \\ ${ }^{1}$ Sansom Institute for Health Research, School of Pharmacy and Medical Sciences, \\ University of South Australia, Adelaide, SA 5001, Australia \\ ${ }^{2}$ School of Engineering, University of South Australia, Adelaide, SA 5095, Australia \\ aliping.wang@mymail.unisa.edu.au, bcory.xian@unisa.edu.au \\ 'Hung-Yao.Hsu@unisa.edu.au \\ ${ }^{*}$ Corresponding author
}

Keywords: Modal Analysis, Cell, Finite Element Analysis.

\begin{abstract}
In this study, the dynamic properties of a cell in vitro are analyzed using the finite element (FE) model. An idealized FE model of a bone cell is developed, and then FE analysis is performed to study its vibration in vitro. The first ten natural frequencies of the bone cell can be obtained using the FE method, which are 11.35 $\mathrm{Hz}, 11.39 \mathrm{~Hz}, 15.51 \mathrm{~Hz}, 23.38 \mathrm{~Hz}, 25.64 \mathrm{~Hz}, 25.71 \mathrm{~Hz}, 30.82 \mathrm{~Hz}, 30.89 \mathrm{~Hz}, 35.27 \mathrm{~Hz}$ and $35.34 \mathrm{~Hz}$, respectively. The mode shapes of the first ten modes are presented as well. In addition, the frequencies of $1-80 \mathrm{~Hz}$ and acceleration of $0.5 \mathrm{~g}\left(9.8 \mathrm{~m} / \mathrm{s}^{2}\right)$ of base vibration have been applied to the harmonic vibration analyses. The relationship of displacement versus frequency is plotted based on the responses for the harmonic vibration. This study will help us further understand the in vitro vibration characteristic of a cell.
\end{abstract}

\section{Introduction}

According to previous studies $[1,2]$, the vibration frequency is very important for bone cells to implement some processes, like bone resorption and bone formation. Generally, the range of vibration frequencies is selected between $1 \mathrm{~Hz}$ and $100 \mathrm{~Hz}$ for the bone cell in-vitro studies $[3,4]$.

The aim of this study was to investigate the vibration responses of a bone cell osteoblast in vitro using the FE method. Firstly, the natural frequencies and mode shapes of FE models were obtained. Furthermore, the harmonic analyses were carried out with base excitation $0.5 \mathrm{~g}$ and a vibration frequency range between 1 and $80 \mathrm{~Hz}$. Finally, the response curves of displacement versus frequency were obtained. This study can provide guide and references for vibration experiments of bone cells in vitro.

\section{Materials and Methods}

\section{Geometry}

Based on the images of the cells in vitro [5], an idealized modelling was developed using FE software ABAQUS (Fig. 1). The cell is comprised of three parts, i.e. cell membrane, cytoplasm and nucleus. In this study, the whole volume of the cell is about $3000 \mu \mathrm{m} 3$, the volume of the nucleus is $\sim 105 \mu \mathrm{m} 3$, the membrane thickness is $\sim 6 \mathrm{~nm}$ [6-8] and the cell height is $\sim 13 \mu \mathrm{m}$. A shell element S4R and a solid element C3D8R were used to represent cell membrane and cytoplasm/nucleus, respectively. 

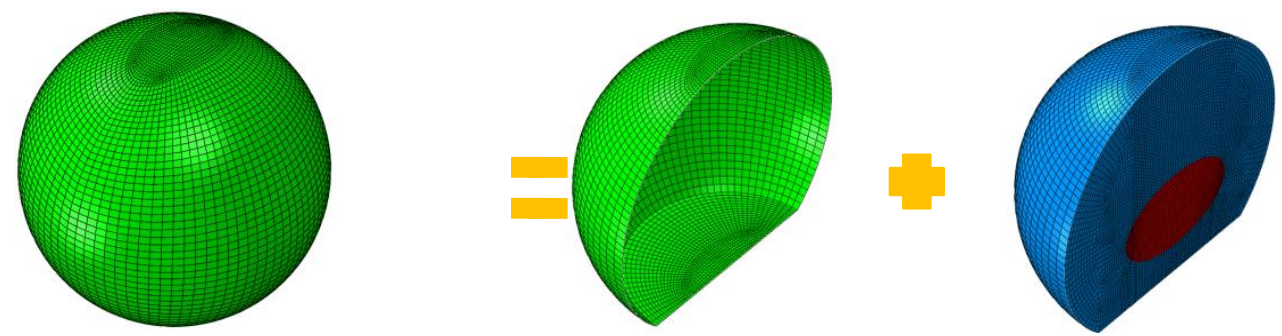

Figure. 1 Finite element modelling of a osteoblast. (a) The whole model; (b) cell membrane and (c) cytoplasm and nucleus.

\section{Material Properties}

The linear elastic isotropic material property was used in this study. The material properties of a bone cell are presented bellow [8, 9]: Young moduli of the cell membrane, cytoplasm and nucleus are $1 \mathrm{kPa}, 1.5 \mathrm{kPa}$, and $6 \mathrm{kPa}$, respectively. Poisson's ratios of the cell membrane, cytoplasm and nucleus are $0.3,0.37$ and 0.37 , respectively. Densities of the cell membrane, cytoplasm and nucleus are $600 \mathrm{~kg} \cdot \mathrm{m}^{-3}$, $1500 \mathrm{~kg} \cdot \mathrm{m}^{-3}$ and $1800 \mathrm{~kg} \cdot \mathrm{m}^{-3}$, respectively.

\section{Modal Analyses}

Natural frequencies can be obtained using ABAQUS. The governing dynamic response equation of vibration of a bone cell may be expressed in Eq. (1) [10]

$$
M \ddot{u}+C \dot{u}+K u=F \text {. }
$$

where $\mathrm{M}, \mathrm{C}$ and $\mathrm{K}$ are mass matrix, damping coefficient matrix and spring stiffness matrix in the system, respectively. $\mathrm{F}$ is loading, and $\tilde{u}, \tilde{u}$ and $u$ are the acceleration vector, velocity vector and displacement vector, respectively.

The undamped vibration of the system and only one degree-of-freedom (DOF) were considered in this study. In the FE simulation, the bottom surface of model was fixed.

\section{Results and Discussion}

Table 1. Natural frequencies for the first ten modes of the finite element model of a bone cell.

\begin{tabular}{cc}
\hline Mode Number & Natural Frequency $(\mathrm{Hz})$ \\
\hline 1 & 11.35 \\
2 & 11.39 \\
3 & 15.51 \\
4 & 23.38 \\
5 & 25.64 \\
6 & 25.71 \\
7 & 30.82 \\
8 & 30.89 \\
9 & 35.27 \\
10 & 35.34 \\
\hline
\end{tabular}






(a)

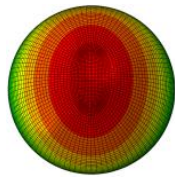

(b)

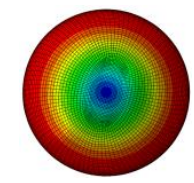

(c)

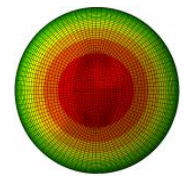

(d)

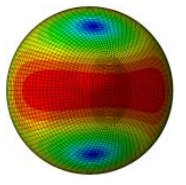

(e)

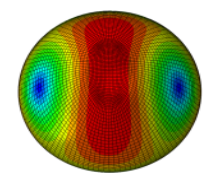

(f)



(g)

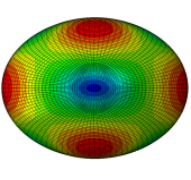

(h)

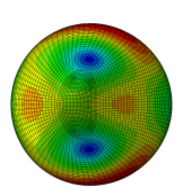

(i)

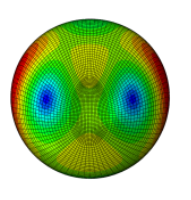

(j)

Figure. 2 Shapes of the first ten modes (viewed from the top) of the finite element model of a bone cell. (a) The 1st mode; (b) 2nd mode; (c) 3rd mode; (d) 4th mode; (e) 5th mode; (f) 6th mode; (g) 7th mode; (h) 8th mode; (i) 9th mode and (j) 10th mode.

The natural frequencies were extracted for the first ten modes of the FE model (Table 1). In addition, the vibration mode shapes of the cell were obtained for the first ten modes of the FE model (Fig. 2).

The natural frequencies of the first ten modes of the bone cell are $\sim 11.35-35.34$ $\mathrm{Hz}$ (Table 1). The natural frequencies of a bone cell were previously obtained by other studies. For examples, the first ten natural frequencies were $\sim 9.95-211.05 \mathrm{~Hz}$ [11] and the first five natural frequencies were $\sim 18.11-21.05 \mathrm{~Hz}$ [12]. Compared with these previous results, it can be found that the natural frequencies obtained by our FE model are consistent with the values in the literature.



(a) 


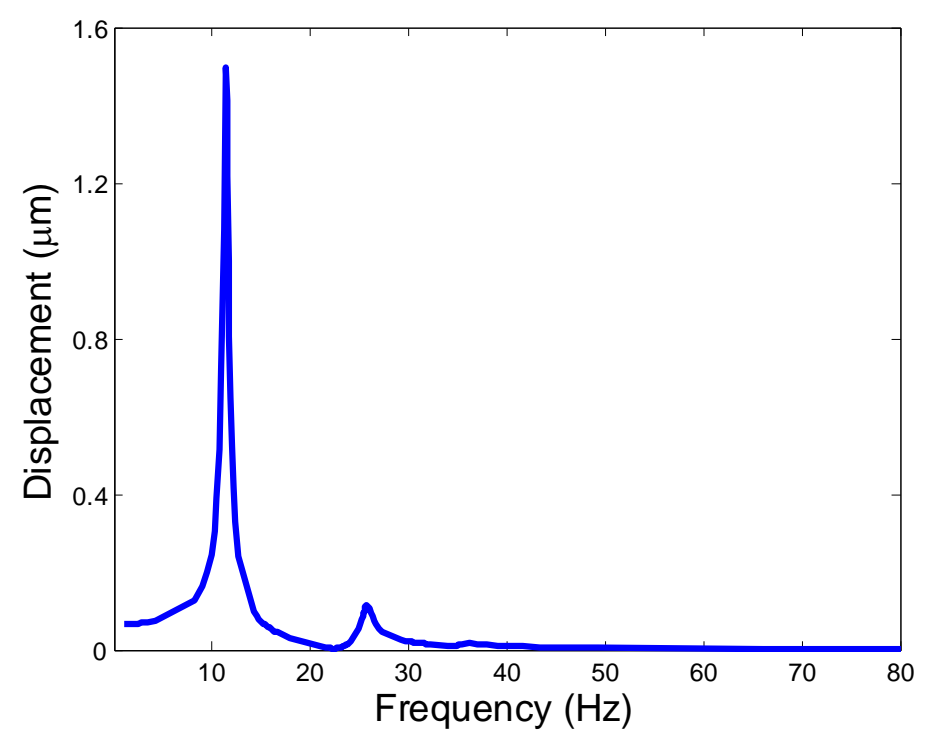

(b)

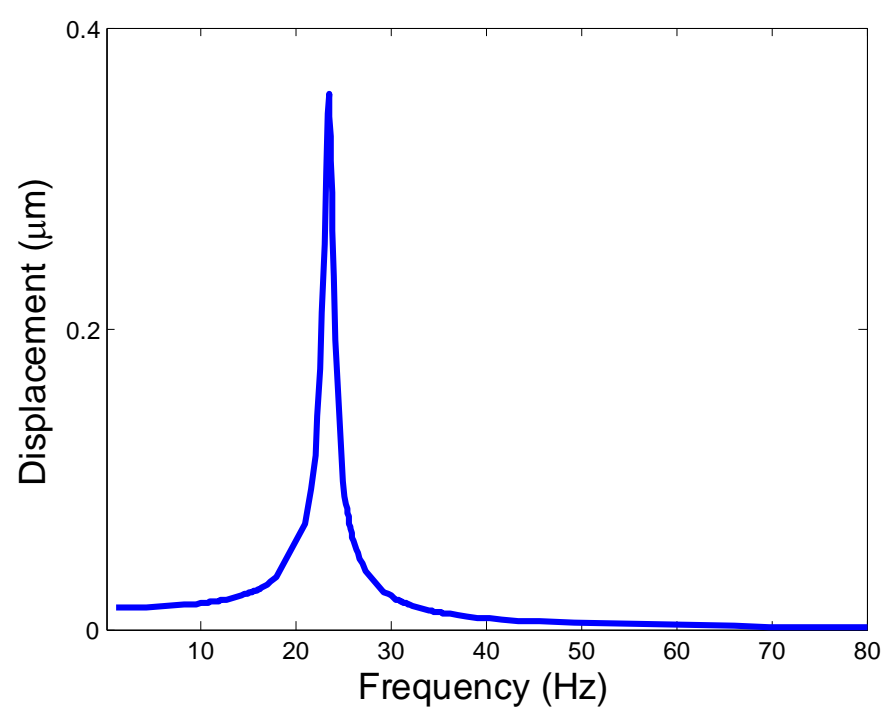

(c)

Figure. 3 The relationship between the displacement of the centre of nucleus and the natural frequency of the bone cell in different directions. (a) $0.5 \mathrm{~g}$ acceleration in X-direction; (b) $0.5 \mathrm{~g}$ acceleration in $\mathrm{Y}$-direction and (c) $0.5 \mathrm{~g}$ acceleration in Z-direction.

In addition, from Fig. 3, it can be clearly observed that the peak values of the displacement of the center point of the cell are nearly the same and occur at nearly the same frequency for the X-direction and Y-direction. While for the Z-direction, the peak displacement value of the center point of the cell is smaller than those of the other directions (X-direction and $\mathrm{Y}$-direction) and occurs at the fourth mode of natural frequency. The differences caused by the shape of a cell are also apparent (Fig. 1).

\section{Conclusion}

In this present study, a FE model was developed to conduct the vibration analyses of a osteoblast in vitro. The natural frequencies were extracted which were between 11.35 $\mathrm{Hz}$ and $35.34 \mathrm{~Hz}$. This range accords with data from the previous studies. 
Furthermore, the harmonic analysis was carried out to analyze the vibration responses for the base excitation with $0.5 \mathrm{~g}$ and frequency range between 1 and $80 \mathrm{~Hz}$. The results showed that the peak values of the displacement of center point of the cell occurred at the first mode natural frequency for the X-direction and Y-direction. The peak value of the displacement center point of the cell occurred at the fourth mode natural frequency for the Z-direction, and this is because that the shapes of a cell are different in three directions.

\section{Acknowledgments}

LW is supported by Australian National Health and Medical Research Council (NHMRC) Postgraduate Research Scholarship grant, and CJX is supported by a NHMRC Senior Research Fellowship.

\section{References}

[1] Lau, E., et al., Effect of low-magnitude, high-frequency vibration on osteocytes in the regulation of osteoclasts. Bone, 2010. 46(6): p. 1508-1515.

[2] Tirkkonen, L., et al., The effects of vibration loading on adipose stem cell number, viability and differentiation towards bone-forming cells. Journal of The Royal Society Interface, 2011. 8(65): p. 1736-1747.

[3] Rosenberg, N., M. Levy, and M. Francis, Experimental model for stimulation of cultured human osteoblast-like cells by high frequency vibration. Cytotechnology, 2002. 39(3): p. 125-130.

[4.] Bacabac, R.G., et al., Bone cell responses to high-frequency vibration stress: does the nucleus oscillate within the cytoplasm? The FASEB journal, 2006. 20(7): p. 858-864.

[5] Frisch, T. and O. Thoumine, Predicting the kinetics of cell. Journal of biomechanics, 2002. 35(8): p. 1137-1141.

[6.] Abolfathi, N., G. Karami, and M. Ziejewski, Biomechanical cell modelling under impact loading. Int J Model Simul, 2008. 28(4): p. 470-476.

[7.] Kamm, R., A. McVittie, and M. Bathe, On the role of continuum models in mechanobiology. ASME APPLIED MECHANICS DIVISION-PUBLICATIONS-AMD, 2000. 242: p. 1-12.

[8.] McGarry, J.G., et al., A comparison of strain and fluid shear stress in stimulating bone cell responses - a computational and experimental study. The FASEB journal, 2005. 19(3): p. 482-484.

[9.] Uzer, G., et al., Gap junctional communication in osteocytes is amplified by low intensity vibrations in vitro. PloS one, 2014. 9(3).

[10] ABAQUS, V., 6.14 Documentation. Dassault Systemes Simulia Corp., Providence, RI, USA, 2014.

[11] Wee, H. and A. Voloshin. Modal analysis of a osteoblast cell in culturing. in Bioengineering Conference (NEBEC), 2012 38th Annual Northeast. 2012. IEEE. 
[12] Wee, H. and A. Voloshin, Dynamic Analysis of a Spread Cell Using Finite Element Method, in Mechanics of Biological Systems and Materials, Volume 4. 2014, Springer. p. 135-140. 